\title{
A SURVEY OF HETEROCYSTOUS NITROGEN-FIXING CYANOBACTERIA IN CHILEAN RICE FIELDS
}

\section{UN CATASTRO DE CIANOBACTERIAS HETEROCISTICAS FIJADORAS DE NITROGENO EN LOS CAMPOS ARROCEROS DE CHILE}

\author{
Iris Pereira ${ }^{1}$, M. Moya ${ }^{1}$, G. Reyes ${ }^{2} \&$ V. Kramm² \\ ${ }^{1}$ Instituto de Biología Vegetal y Biotecnología, Universidad de Talca, Casilla 747, Talca, Chile. \\ ipereira@utalca.cl. \\ ${ }^{2}$ Instituto Nacional de Investigaciones Agropecuarias, INIA Quilamapu, Vicente Méndez 575, Chillán, Chile.
}

\begin{abstract}
The purpose of this study was to increase knowledge of the nitrogen-fixing cyanobacteria communities of Chilean rice fields. To this end, we sampled 34 rice fields situated between latitudes $34^{\circ} 30^{\prime}$ and $36^{\circ} 36^{\prime} \mathrm{S}$ in central Chile. At each site, two water samples and one soil sample were taken. Samples were fixed in $4 \%$ formalin before taxonomic determination. A total of 12 filamentous heterocystous taxa were determined, nine of which have not previously been recorded in Chile. For each taxon, a description based on morphological and reproductive characters was made and recorded along with information on the geographical distribution in the study area.
\end{abstract}

Keywords: Anabaena, Aphanizomenon, Cylindrospermum, Gloeotrichia, Nostoc.

\section{RESUMEN}

El propósito de este estudio fue incrementar el conocimiento de las comunidades de cianobacterias fijadoras de nitrógeno en los campos arroceros chilenos. Para este fin, nosotros muestreamos 34 arrozales situados entre latitudes $34^{\circ} 30^{\prime}$ y $36^{\circ}$ 36' S en Chile central. En cada sitio, se tomaron 2 muestras de agua y una de suelo. Las muestras fueron fijadas en formalina al $4 \%$ y fueron usadas para la determinación taxonómica. A total de 12 taxa filamentosas heterocísticas fueron determinados, nueve de los cuales no han sido previamente registrados en Chile. Para cada taxón, se hizo una descripción basada en caracteres morfológicos y reproductivos y se registró información acerca de la distribución geográfica en el área de estudio.

Palabras claves: Anabaena, Aphanizomenon, Cylindrospermum, Gloeotrichia, Nostoc.

\section{INTRODUCTION}

To date there has been little taxonomic and floristic study of filamentous heterocystous nitrogen-fixing Cyanobacteria in Chilean rice fields. We are aware of only two studies, which have reported the presence of two taxa of this group: Gloeotrichia natans Rabenh. ex Bornet \& Flahault (Parra et al. 1982, Pereira et al. 2000) and Cylindrospermum muscicola Kützing ex Born et Flah.var. longispora Dixit (Pereira et al. 2000). Nevertheless, it is likely that filamentous heterocystous nitrogen-fixing cyanobacteria have an important role in the nitrogen cycle in the soils of Chilean rice fields (Pereira et al. 2004). The distribution in these taxa in Chilean rice fields is therefore of potential economic relevance.

Here we analyse communities of filamentous heterocystous nitrogen-fixing Cyanobacteria at 34 sites situated between latitudes $34^{\circ} 30^{\prime}$ and $36^{\circ} 36^{\prime}$ $\mathrm{S}$ in the rice-growing region of central Chile. The knowledge about distribution of the taxa obtained from this survey may help identify sources of cyanobacteria for use as biofertilizers in rice cultivation on nitrogen-poor or degraded soils. 


\section{MATERIALS AND METHODS}

STUdy AREA

The study area encompassed a total of 34 sites situated between $34^{\circ} 30^{\prime}$ and $36^{\circ} 36^{\prime} \mathrm{S}$ in the ricegrowing region of central Chile (Table I). Most sites were located in the Central Valley, at altitudes between 100 and $200 \mathrm{~m}$. a.s.l. Temperatures of most of the waters that were sampled were between $20^{\circ} \mathrm{C}$ and $25^{\circ} \mathrm{C}$ during the growing season (October-March), and $\mathrm{pH}$ ranged from 5.5 to 7.0 .

Collection of algal material

At each site two water samples and one of soil were taken. The water samples were fixed in formalin before taxonomic determination. The soil sample was obtained introducing a glass tube in the water-soil interface to a depth of $5-6 \mathrm{~cm}$. The sample was homogenised, a $1 \mathrm{ml}$ extract was obtained from the suspension, and $\mathrm{pH}$ adjusted to 5.5. One $\mathrm{ml}$ of each of three dilutions $10^{-1}, 10$ ${ }^{2}$ and $10^{-3}$ was sowed in Petri plates enriched with Agar-Watanabe medium. The first cyanobacterial thalli began to appear within about three weeks. Thalli were then fixed with $4 \%$ formalin before taxonomic determination.

\section{TAXONOMIC DETERMINATION}

Taxonomic determination of the species was performed with the aid of a Kyowa stereoscopic magnifier and a Nikon Optiphot microscope equipped with a reflex camera and a graduated eye-piece. Specialized bibliography was also consulted (Desikachary 1959; Geitler 1932. The vegetative and reproductive characters used for taxonomic determination were: shape, colour and size of the thallus; breadth and length of trichomes; shape, size and colour of vegetative cells, heterocysts and akinetes, as well as texture and ornamentation of cell walls of akinetes.

\section{RESULTS}

ABUNDANCE AND DISTRIBUTION OF TAXA

A total of twelve filamentous heterocystous taxa were determined (Table I). Two of them had been previously reported in Chilean rice soils: Gloeotrichia natans (Parra et al. 1982, Pereira et al. 2004) andCylindrospermum muscicola var. longispora. Nine represented new records for Chile (Pereira et al. 2004): Anabaena fertilissima, A. iyengarii var. tenuis, A. iyengarii var. unispora, Aphanizomenon holsaticum, Cylindrospermum garakpurense, Nostoc commune, $N$. ellipsosporum, N. linckia, $N$. spongiaeforme var.tenue, and Nostocsp.

The most widespread taxon was Gloeotrichia natans followed by Anabaena iyengarii var. unispora, Cylindrospermum muscicola var. longispora, Nostoc spongiaeforme var. tenue, N. linckia, N. commune, Nostoc sp. and Anabaena iyengarii var. tenuis. Rarer species were Anabaena fertilissima, Aphanizomenon holsaticum, Cylindrospermum gorakpurense and N. ellipsosporum (Table I).

\section{DESCRIPTIONS OF TAXA}

1. Anabaena fertilissima C.B. Rao (Fig. 1). Trichomes single, with cells with rounded ends, up to $310 \mu \mathrm{m}$ long, 5.6-6.4 $\mu \mathrm{m}$ broad. Cells barrel-shaped, 4.8-5.6 $\mu \mathrm{m}$ long. Heterocysts spherical, 6.4-8 $\mu \mathrm{m}$ diameter. Akinetes almost spherical, in long chains, often making the whole trichome sporogenous, 5.6-6.4 $\mu \mathrm{m}$ broad and 3.6-5.6 $\mu \mathrm{m}$ long, with a smooth hyaline outer wall.

Ecology: Periphytic species. Cenobies gelatinous, subspherical, dark blue-green, 1.5-2 cm diameter. This species grows together with other nitrogen fixing algae such as: Gloeotrichia natans, Cylindrospermum muscicola var. longispora, Nostoc spongiaeforme var. tenue and Anabaena iyengarii var. unispora.

2. Anabaena iyengarii Bharadwaja var. tenuis C.B. Rao (Fig. 2).

Gelatinous mass, slender, free-floating, pale bluegreen. Trichomes single, straight or irregularly curved, 4-4.4 $\mu \mathrm{m}$ broad, apical cell conical with rounded apex. Cells barrel-shaped, as long as they are broad or slightly shorter or longer. Heterocysts in the majority. Subspherical, 4.8-6 $\mu \mathrm{m}$ broad and 4.8-7.2 $\mu \mathrm{m}$ long. Akinetes ellipsoidal or cylindrical, with rounded apex, single or in pairs on either side of a heterocyst, 6.4-8 $\mu \mathrm{m}$ broad and 9.6-12 $\mu \mathrm{m}$ long, with a hyaline smooth outer wall. 


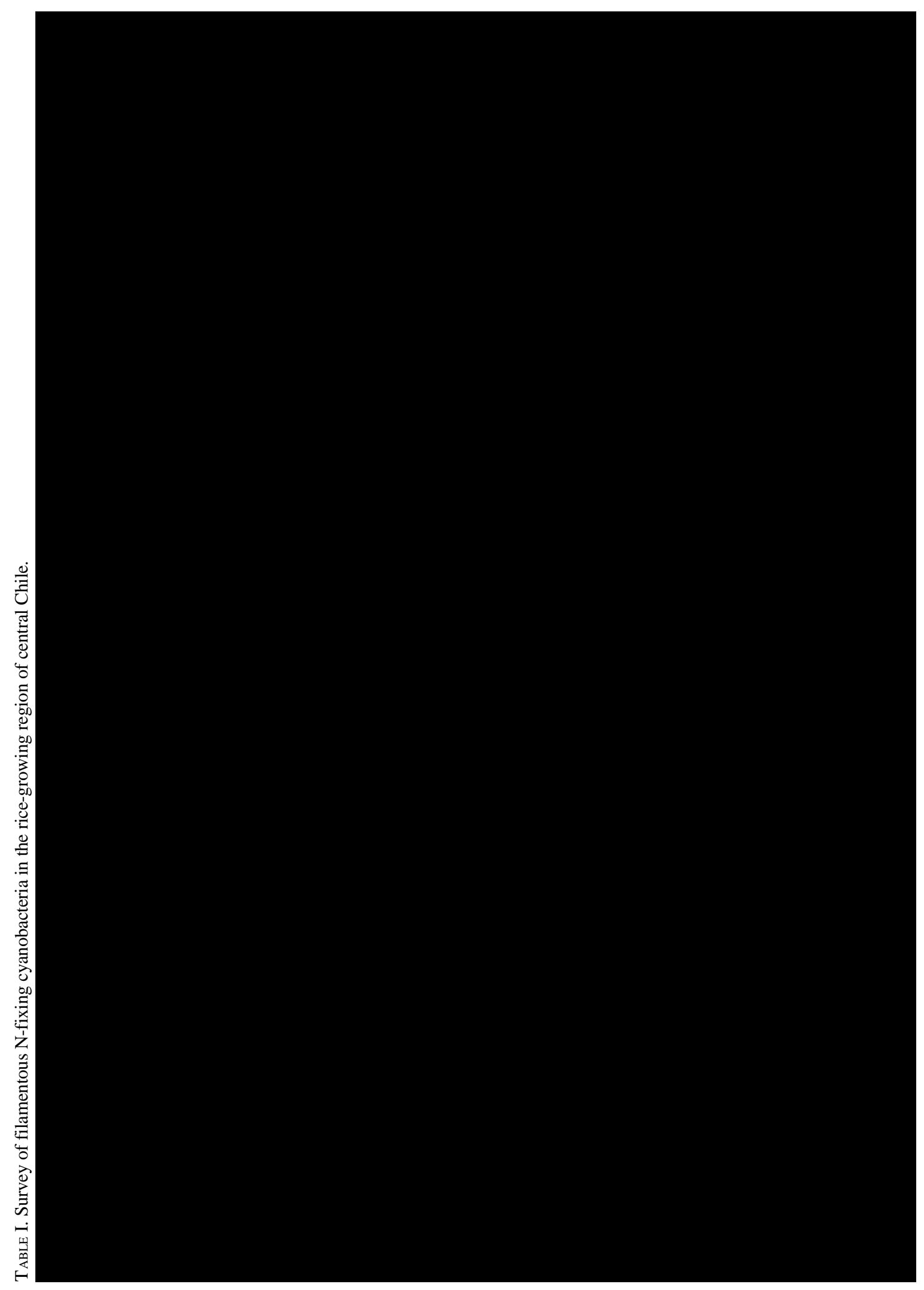


ECOLOGY: Planktonic species, forming a dark green floccose mass on the surface of water. Appears in association with Gloeotrichia natans and Nostoc spongiaeforme var.tenue.

\section{Anabaena iyengarii Bharadwaja var.unispora} Rama N. Singh (Fig. 3).

Mucilaginous mass, dark blue-green. Trichomes single, free-floating 3.2-4 $\mu \mathrm{m}$ broad, with a conical apical cell, with round apex. Cells barrel-shaped or almost square, 4-4.8 $\mu \mathrm{m}$ long. Heterocysts barrelshaped, rarely subspherical, 4.8-7.3 $\mu \mathrm{m}$ broad and 8.8-12.8 $\mu \mathrm{m}$ long. Akinetes ellipsoidal or sub spherical, one on either side of the heterocyst, 13.6$17.6 \mu \mathrm{m}$ broad and 26.4-44 $\mu \mathrm{m}$ long, with smooth and rust-coloured reddish inner wall.

Ecology: Mucilaginous mass of irregular shape appears floating on the surface of the water in rice fields. It has been found associated with Gloeotrichia natans and Cylindrospermum muscicola var. longispora.

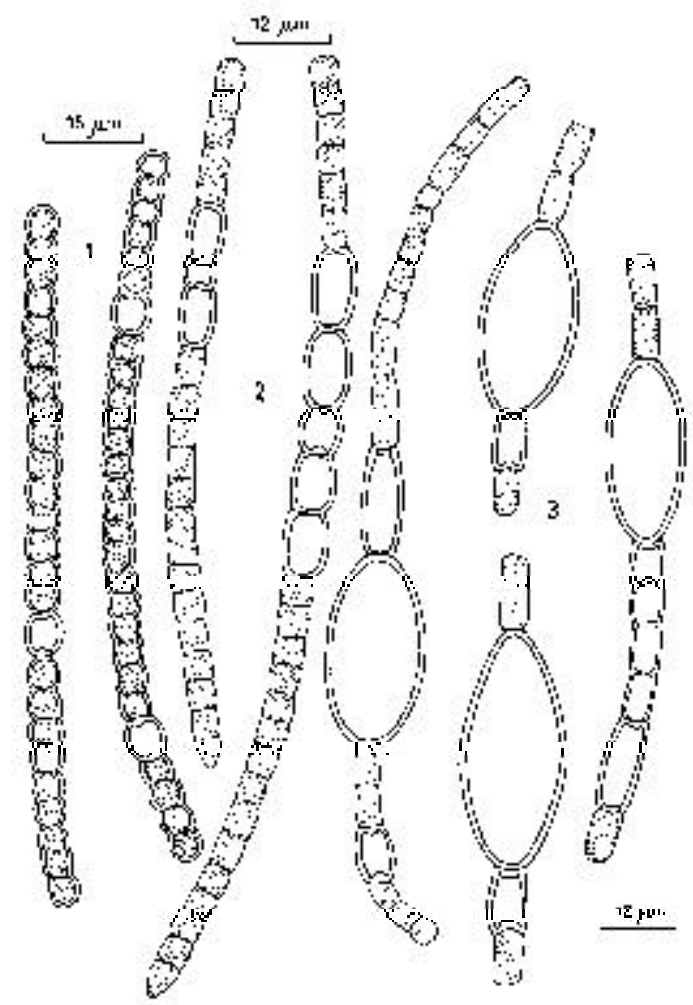

Figures 1-3. Fig. 1: Anabaena fertilissima. Fig. 2: Anabaena iyengarii var. tenuis. Fig.3: Anabaena iyengarii var. unispora.
4. Aphanizomenon holsaticum O. Richt. (Fig. 4). Trichomes have a majority with pointed ends. Cells round, square or rectangular, 5-6 $\mu \mathrm{m}$ broad and 4.8$8 \mu \mathrm{m}$ long. Heterocysts cylindrical or spherical, 6.4$7 \mu \mathrm{m}$ broad and 5.6-9.6 $\mu \mathrm{m}$ long. Akinetes cylindrical, with rounded ends, adjacent to the heterocyst, 7.2-8 $\mu \mathrm{m}$ broad and 12-13 $\mu \mathrm{m}$ long.

Ecology: Planktonic species, very scarce.

\section{Cylindrospermum garakpurense Rama N. Singh} (Fig. 5).

Trichomes blue-green, single, with deep constrictions in the joints, $4-4.8 \mu \mathrm{m}$ broad. Cells cylindrical, 4-4.8 $\mu \mathrm{m}$ broad and 7.2-11.2 $\mu \mathrm{m}$ long. Heterocysts ellipsoidal or almost ellipsoidal, one at each end of the trichome, 4.8-5.6 $\mu \mathrm{m}$ broad and 7.2-10.4 $\mu \mathrm{m}$ long. Akinetes ellipsoidal with rounded apex, sub-terminal at either end of the trichome, 15.2-18.8 $\mu \mathrm{m}$ broad and 24-28 $\mu \mathrm{m}$ long, with a thick yellowish brown outer wall, provided with delicate needle-shaped projections, without exospore, 12-12.8 $\mu \mathrm{m}$ broad.

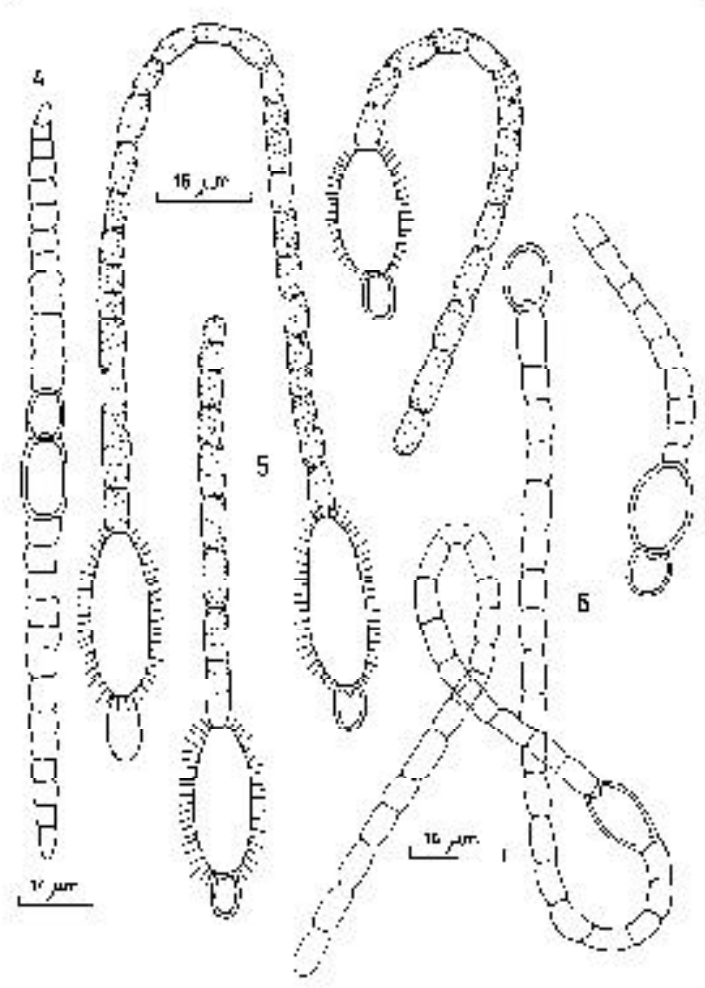

Figures 4-6. Fig. 4: Aphanizomenon holsaticum. Fig. 5: Cylindrospermum gorakpurense. Fig. 6: Cylindrospermum muscicola var. longispora. 
ECOLOGY: Planktonic species, grows on the surface of water forming a green mucilaginous mass. This species grows together with Cylindrospermum muscicola var. longispora and Nostoc spp. Rare.

\section{Cylindrospermum muscicola Kütz. ex Bornet \&} Flahault var. longispora S.C. Dixit (Fig. 6).

Thallus mucilaginous, extended, pale blue-green Trichomes 4-4.4 $\mu \mathrm{m}$ broad. Cells cylindrical or almost square, 6.4-10.4 $\mu \mathrm{m}$ long. Heterocysts oblong, 5.2-7.2 $\mu \mathrm{m}$ broad and 8.8-11.2 $\mu \mathrm{m}$ long. Akinetes oval, 8-12 $\mu \mathrm{m}$ broad and 16-20 $\mu \mathrm{m}$ long, with a smooth yellowish brown epispore.

ECology: Planktonic alga; mucilaginous thallus growing on the surface of water, and a pale bluegreen colour. This alga grows together with Gloeotrichia natans and Anabaena iyengarii var. unispora.

7. Gloeotrichia natans Rabenh. ex Bornet \& Flahault (Fig. 7).

Thallus spherical, up to $10 \mathrm{~cm}$ broad, soft, hollow, blackish olive-green to brown. Filaments loosely arranged. Trichomes 7.2-8 $\mu \mathrm{m}$ broad, olivaceous,

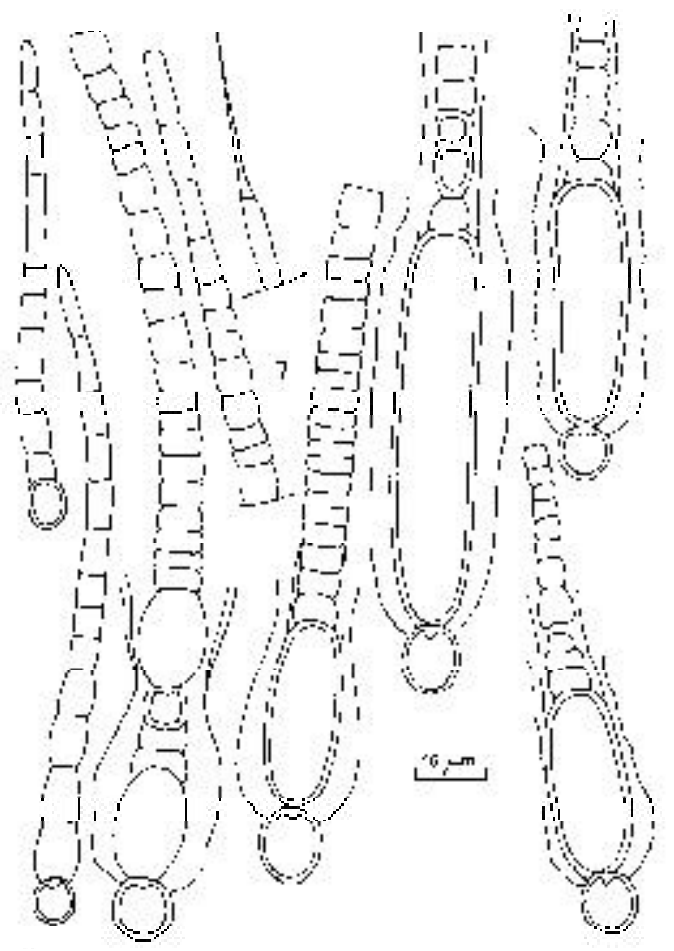

Figure 7. Gloeotrichia natans. attenuated into a long hair. Cells at the base barrelshaped, as long as broad or sometimes shorter. In the upper part, the cells can be up to four times longer than broad. Heterocysts basal, more or less spherical, 4.8-12 $\mu \mathrm{m}$ broad. Akinetes cylindrical, straight or curved, with sheath $12-20 \mu \mathrm{m}$ broad and 34.4-80 $\mu \mathrm{m}$, without sheath up to $36 \mu \mathrm{m}$ broad, saccate, hyaline or brownish and smooth.

Ecology: Planktonic and periphytic species with thallus spherical or subglobose, olive green to brown, that appears attached to submerged plants or free-floating on water surface. Very common at most of the studied sites, where it appears associated with Cylindrospermum muscicola var. longispora, rarely with Anabaena iyengariivar. unispora and with species of the genusNostoc. The most widespread in soils of Chilean rice fields.

8. Nostoc commune Vaucher ex Bornet \& Flahault (Fig. 8).

Thallus firm, gelatinous, first globose, after flattened, expanding, undulated. Filaments flexuous, entangled. Trichomes 4.5-6 $\mu \mathrm{m}$ broad. Cells short barrel-shaped or nearly spherical, 3.2$5.6 \times 2.4-2.8 \mu \mathrm{m}$ Heterocysts sub-spherical or broadly ellipsoidal, 4.8-6.4 x 4.0-4.8 $\mu \mathrm{m}$. Akinetes only sometimes observed, as big as the vegetative cells; small colourless epispore.

ECOLOGY : Species generally benthic, at water-soil interface and more rarely planktonic.

9. Nostoc ellipsosporum (Desm.) Rabenh. (Fig. 9). Thallus gelatinous, expanded irregularly, attached by the lower surface, reddish brown. Filaments flexuous loosely entangled. Trichomes $4 \mu \mathrm{m}$ broad, lightly blue-green or olive: Cells cylindrical, 5.6-6.4 $\mu \mathrm{m}$ long. Heterocysts sub-spherical or oblong, 5.6-6.4 $\mu \mathrm{m}$ broad and 7.2-10 $\mu \mathrm{m}$ long. Akinetes ellipsoidal to oblong-cylindrical, 6.4-6.8 $\mu \mathrm{m}$ broad and 8.8-11.2 $\mu \mathrm{m}$ long, with a soft, hyaline or brownish epispore.

Ecology: Benthic species, associated with Gloeotrichianatans.

10- Nostoc linckia Bornet ex Bornet \& Flahault (Fig. 10).

Thallus variable in size, at first globose later irregularly expanding, gelatinous, blue-green to 


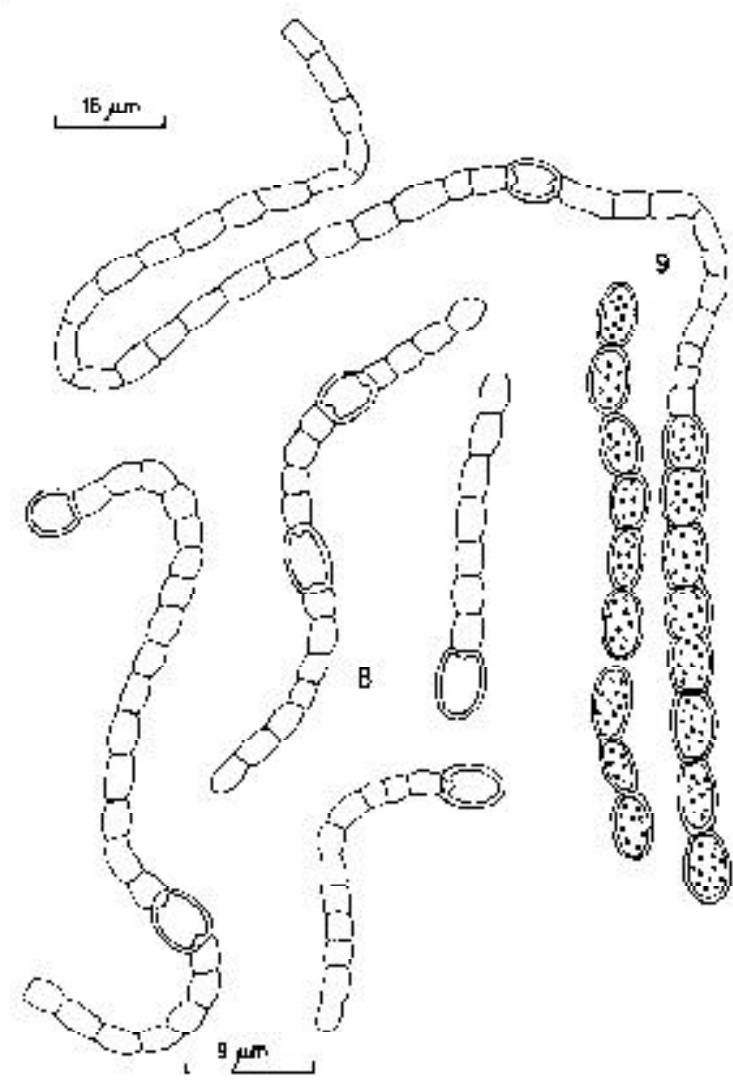

Figures 8-9. Fig. 8: Nostoc commune. Fig. 9: Nostoc ellipsosporum.

violet, or dark green or brown: Filaments densely entangled. Trichomes 3.5-4 $\mu \mathrm{m}$ broad, pale bluegreen. Cells short barrel-shaped. Heterocysts subspherical. Akinetes subspherical, 6-7 $\mu \mathrm{m}$ broad and 7-8 $\mu \mathrm{m}$ long, with a smooth epispore.

Ecology: Benthic species, growing on muddy substrates.

11. Nostoc spongiaeforme C.Agardh. var. tenue C.B. Rao (Fig. 11).

Mass gelatinous, small, slender, expanded, brownish black to brown, sheath hyaline or pale yellow, generally more or less diffluent, occasionally firm: Trichomes densely entangled, $4-4.8 \mu \mathrm{m}$ broad. Cells spherical, subspherical, ellipsoidal or barrel-shaped, those adjoining the heterocysts lightly attenuated, 4-7.2 $\mu \mathrm{m}$ long, ends cells of generally with a pointed apex. Heterocysts spherical, subspherical, ellipsoidal or with barrel-shaped, rarely cylindrical with the flat or rounded ends, 4.8-7.2 $\mu \mathrm{m}$ long. Akinetes in chains 3-15, spherical, subspherical or ellipsoidal, 8-9.6 $\mu \mathrm{m}$ broad and 8-9.6 $\mu \mathrm{m}$ long, hyaline and smooth outer wall.

Ecology: Generally benthic species, grows at the water-soil interface with the appearance of a gelatinous mass. Sometimes associated withAnabaenaiyengarii var. unispora, Cylindrospermum muscicola var. longispora and Gloeotrichia natans.

\section{Nostoc sp. (Fig. 12).}

Thallus very small, blue-green. Filaments not densely entangled, blue-green. Cells short barrel-shaped, 3.2$4.0 \times 2.8-3.2 \mu \mathrm{m}$. Heterocysts ellipsoidal, 4.0-4.8 x 3.2-3.6 $\mu \mathrm{m}$. Akinetes not found.

Ecology: Planktonic species, appears on the water surface.

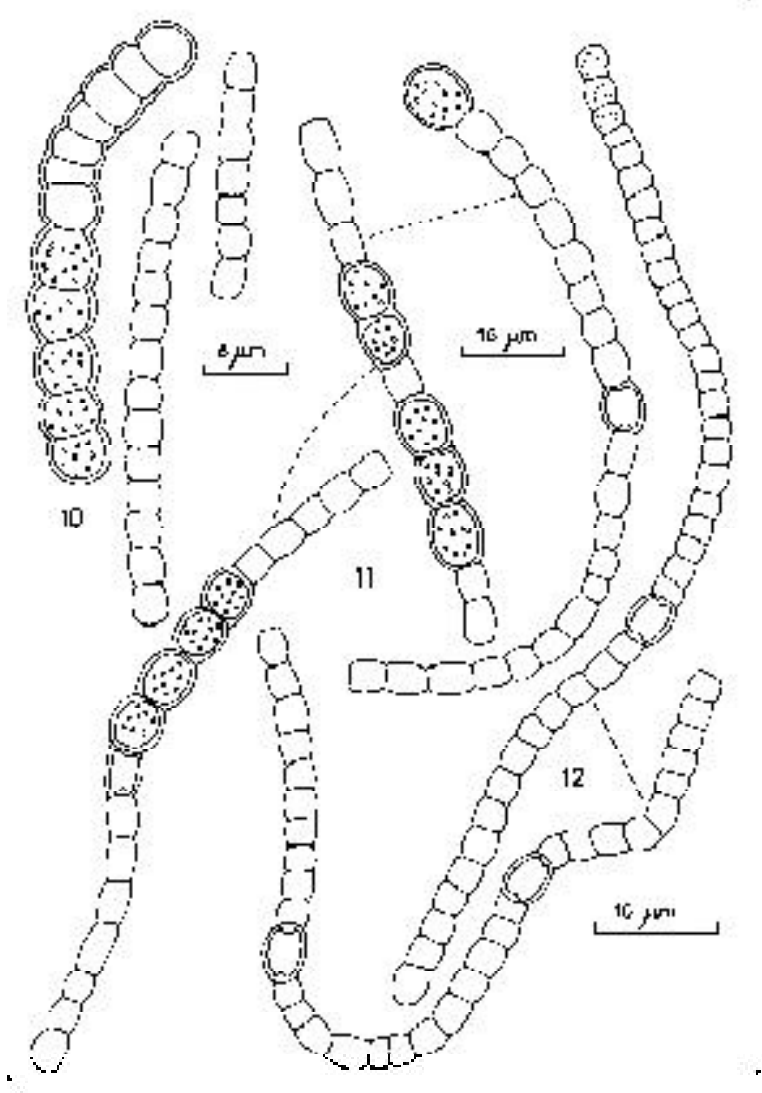

Figures 10-12. Fig. 10: Nostoc linckia. Fig. 11: Nostoc spongiaeforme. Fig. 12: Nostoc sp. 


\section{ACKNOWLEDGEMENTS}

The authors gratefully acknowledge the financial support of "Fundación para la Innovación Agraria" (FIA), Universidad de Talca, and INIA Quilamapu. We also thank Dr. Peter Caligari for the revision of the English of the manuscript, and Mr. Pedro Arias for the confection of the Indian ink drawings.

\section{BIBLIOGRAPHY}

Desikachary, T.V. 1959. Cyanophyta. Indian Council of Agricultural Research. New Delhi. 685 pp.

Geitler, L.1932. Cyanophyceae in Rabenhorst's Kryptogamen Flora, Leipzig 14: 1196 pp.
Parra, O., M. González, V. D ellarossa, P. Rivera \& M. Orellana. 1982. Manual taxonómico del fitoplancton de aguas continentales con especial referencia al fitoplancton de Chile. I. Cyanophyceae. Editorial Universidad de Concepción. 70 pp.

Pereira, I., G. Reyes y V. Kramm. 2000. Cyanophyceae, Euglenophyceae, Chlorophyceae, Zygnematophyceae y Charophyceae en arrozales de Chile. Gayana Botanica 57: 29-53.

Pereira, I, M. M oya, G. Reyesy V. Kramm. 2004. Manual divulgativo: Obtención de biofertilizantes a partir de algas verde-azules y su introducción por primera vez en prácticas agronómicas del arroz en Chile. FIA. Ministerio de Agricultura, Chile. 62 pp. 